\title{
REIMAGINING EDUCATION FOR TRANSFORMATION AND SOCIAL CHANGE: A CASE STUDY OF INTEGRATED LEARNING AT UCBC IN THE DRC
}

\author{
K. H. Bunduki \\ 'Université Chrétienne Bilingue du Congo' \\ (Christian Bilingual University of the Congo) \\ Democratic Republic of the Congo \\ e-mail: honore.bunduki@congoinitiative.org and bhonorekwani@gmail.com
}

\author{
L. G. Higgs \\ Department of Educational Foundations \\ University of South Africa \\ Pretoria, South Africa \\ e-mail: higgslg@unisa.ac.za
}

\section{ABSTRACT}

This article examines the contribution that integrated learning can make to education for transformation and social change at the 'Université Chrétienne Bilingue du Congo' (UCBC) in the Democratic Republic of the Congo. A description of the integrated learning as an igniter of transformation in learners was obtained through the analysis of data collected from twelve alumni through semi-structured interviews. An explanation of how learners are impacted through integrated learning to serve as change agents in their communities also emerged from the data analysis. In fact, the curriculum at UCBC was described as having multiple components and dimensions. This curriculum equips learners with academic knowledge and skills, and it fosters character and servant leadership skills in them. Five major components of the curriculum were unveiled: academic training, special skills training, work program, service-learning and community life. The dimensions of the curriculum are affective, social and relational. Learning occurs in a family-like environment characterized by accessibility and free interactions between members of the campus community. The curriculum functions under an overall Christian worldview. As a result of the educational process they underwent students became role models and learning-teachers to their colleagues and community members.

Key terms: Christian university, curriculum, integrated learning, servant leadership, transformation, triadic training

\section{INTRODUCTION}

Education, Nelson Mandela said, is the great engine of personal development. Good education triggers personal development and it fosters character in learners to build them up to be of value 
to their society. In other words, besides academic competence, good education ignites inner transformation in learners; it helps learners acquire servant leadership skills for social responsibility (Nemerowicz and Rosi 1997).

This article examines what an education for transformation and social responsibility can look like in sub-Saharan Africa context. The article explores the type of curriculum that is designed to impact learners' personal lives; it also seeks to understand how learners themselves understand the transformation they experienced during their training in integrated learning. The impact of a specially designed curriculum on the transformation of education is examined through lived experiences of twelve alumni from the 'Université Chrétienne Bilingue du Congo' (UCBC) in the North-Kivu province of the Democratic Republic of the Congo (DRC).

The purpose of this work is to describe the curriculum that triggers transformation in learners, how and why it does so. Results of this research can inspire many other educational institutions to reimagine their approach to training learners in contexts other than the DRC.

\section{LITERATURE REVIEW}

\section{Integrated learning curriculum and education for social responsibility}

Approaches to education can be summed up in four kinds of curricula: a humanistic curriculum, a social reconstructionist curriculum, a technological curriculum and an academic subject-based curriculum (see, Luke, Woods and Weir 2013; McNeil 1985). In the attempt to design new approaches to education most institutions either elaborate one of these types of curricula to adapt it to their own context, or they take a more eclectic stand combining elements from some or all the four types of curricula. Whatever the adopted approach, the curriculum remains a key element to the educational process. It determines the who, the what, the how, the with what and the what for in the process of good education.

The integrated learning curriculum that this article focuses on falls under the category of academic subject-based curriculum. According to McNeil $(1985,58)$ the academic subjectbased curriculum (ASC) insists on triggering excellence through providing learners with a list of needed academic subjects designed to equip them for equity and social justice. ASC has three main approaches. The first approach, known as an approach based on forms of knowledge, in which learners are trained not simply by recalling facts but by acquiring and justifying learned facts. In the second approach, the integrated studies approach, different subjects in different modes, are integrated into unifying themes for learning to take place in an eclectic and integrated manner. The third approach takes learners back to the acquisition of basic skills such 
as, reading, writing, and solving mathematical problems as a point of departure for teaching and learning. This trend is referred to as the basic education approach (BEA).

In the Democratic Republic of the Congo, ASC particularly, the BEA trend, is the most used approach to education (N'Sial 2007). But contrarily to common practice, UCBC has designed an eclectic integrated learning curriculum that combines the three trends in the academic subject curriculum with the other three types of curriculum. UCBC curriculum emphasizes excellence in academic enquiry and community engagement through training students in academic subjects and through emphasizing the humanistic and social reconstructionist aspect of learning. This second emphasis is accounted for through the collaborative/interactive learning and community life aspect learners experience in various structural settings and through two other components of the curriculum which are work program and service learning. UCBC curriculum also promotes training in new technology handling and bilingual learning (English and French) to prepare learners as citizens of a global world. Finally, UCBC curriculum prioritizes the integration of faith and learning under an overall Christian worldview.

Nevertheless, the integration of faith and learning here referred to needs to be clarified. In his book The idea of a Christian College, Holmes (1987) ably articulates the Christian perspective to integration in learning. According to him, the integration of faith and learning simply implies that all undertakings in education: social, intellectual or cultural are guided by Christian values and learning is looked at holistically as an act that sees life as a whole from a Christian perspective (Holmes 1987, 77). For Holmes and other Christian scholars (Glanzer 2008; VanZanten 2011) the faith and learning integration in Christian understanding insists on the redemption of all aspects of the good God-created order distorted by the fall of man. God is the Creator of all things and the source of the ultimate truth. Therefore, critical thinking promoted by Mezirow's Transformative Learning Theory (TLT) does not set man and God heads on nor does it oppose Bible and science. The guiding principle for informed Christian scholars Briscoe $(1987,33)$ says is simple and stated as following: 'Scripture rightly understood is the final authority and science properly conducted and applied serves to amplify and elaborate on the gracious revelation God gives mankind'.

In the Democratic Republic of the Congo (DRC), as in some sub-Saharan countries, university curricula have always been academic subject-oriented. The educational practice emphasizes training the mind/intellect, theory and memorization. This is a legacy from colonization. Colonizers actually denied nationals free expression, and nationals were taught not to question anything but to simply say 'yes' to anything colonizers, the authority images of 
the time, required. This practice has been passed over into the educational system. Learners are assumed not to question but to memorize and recite what the teacher, the figure of authority, tells them, and no room is left for critical thinking. This colonial legacy has largely contributed to consolidate the cultural and social hierarchical order already existent in the Congolese society.

A need for a re-imagination of the educational process was, therefore, evident so that learners could experience humanness, autonomous thinking and genuine transformation from inside out as ably suggested by Mezirow in his transformative learning for adults. Transformative Learning facilitates the adult learner's move from his/her natural tendency to stick and act in line with preconceived ideas to acting in a more inclusive, self-reflective and integrated way. He/she embraces life experiences and circumstances as they come his/her way. Such educational experience initiates transformation.

Mezirow (1997; 2012) acknowledges four ways learning occurs for any adult learner to experience transformation. Learning can occur through the elaboration of existing frames of reference or 'habits of mind' or through discovering new frames of reference. Learning can also occur through the transformation of 'points of view' or through the transformation of habits of mind.

'Habits of mind' are specific point of view vantages or codes that direct all realms of human life whether cultural, social, economic, political, educational or psychological. They are deeply anchored in the worldview and personality of the adult person. But 'points of view' simply stem from 'habits of mind' and constitute the expression of inner realities or the surface layer of inner realities. Education that proposes to be transformational has to challenge both 'habits of mind' and 'points of view' where necessary and lead learners towards a shift from old assumptions to new ones. The educational curriculum serves as a catalyst that challenges learners' old 'habits of mind' and 'points of view' and helps learners develop new assumptions, when necessary, in all aspects of life and for the usefulness of their communities and to themselves.

While Mezirow (1997) particularly emphasizes critical and autonomous thinking in the learning process, his followers elaborated on the affective, social, relational and spiritual dimension of transformative learning. Today, the TLT offers a frame in which transformative learning can be explained through its impact in personal lives and in social change separately. Gunnlaugson (2008) recognizes that a more unifying transformative theory is yet to be unveiled to close the gap between personal transformation and social change. However, an effort has been made by Cranton and Taylor (2012) together with other scholars in the field of 
transformative learning to present all facades of the theory in a unique work. Each contributor describing a separate aspect of the theory opens the way forward for the unification of the theory that would be established through single stances of experiences of both personal and community transformation, triggered by a special educational curriculum.

This article presents a first leg towards the unification consisting of the description of the integrated learning curriculum that ignites personal transformation in learners and of the examination of how personal transformation happens. The article examines the case of alumni from the Christian Bilingual University in DRC who received integrated learning. These alumni then went to serve in their respective communities as change agents. Their experiences reveal the possibility that exists to induce transformation in learners through a specially designed curriculum and the challenges that are inherent to the implementation of such curriculum and to the role of acting as an agent of change in the community.

\section{Integrated learning at UCBC and education for transformation}

UCBC is a Christian university established in 2007 and chartered by the DRC government in 2010. The vision of the university stems from the organisation that created it, Congo Initiative. The university exists 'to train and develop strong, indigenous Christian leaders to transform their communities and their nation of the Democratic Republic of Congo'. This vision stems from the biblical text of Isaiah 43:18-19. ${ }^{1}$ The mission of UCBC is 'to model, nurture and shape an authentic, redemptive community of Christ's followers whose calling is to transform the society in the Democratic Republic of Congo’. In 2009, the mission of UCBC was revisited and translated in action terms and achievable objectives so that after completion of studies at UCBC a student should be able to formulate relevant solutions to problems in the society as they conciliate knowledge and practice, demonstrate expertise in their fields of study and competence in dialogue and interactive learning. UCBC graduates should also be able to integrate mind, emotion, and body in theology, politics, and business for individuals and communities and exhibit servant, Christ-like character as agents of transformation. Finally, they, UCBC graduates, should be able to model, nurture, and shape an authentic Christian community in the process of transformation as they lead the transformation of their communities, nation, and the world.

To assure that its mission is accomplished UCBC offers general education courses and faculty core courses to address the academic objective of the university. The other objectives are met through service learning, work program and extra-curricular activities such as one hour chapel sessions every Monday and Friday, a reflection day every last Wednesday of the month, 
mentoring group meetings once a month; peer group meetings once a month; 'exposé' every Wednesday; student initiated club and organization activities (African Youth Leadership Forum - AYLF, Youth With a Mission - YWM, University Youth for Development and Change UYDC, Truth and Transformation - TNT Movie Club, Women's Voice), football and basketball teams (girls and boys), excursions, as well as, radio broadcastings on the university radio channel.

UCBC constantly strives for 'academic excellence, specialization within faculty, interdisciplinary competency, bilingual education, character formation, servant leadership and community engagement' (UCBC 2009). Five faculties are organized at UCBC: Theology, Economic Sciences, Communication Sciences, Applied Sciences and the Law faculty, the last born of all faculties, which trains lawyers with the mission to impact the judiciary system of the country.

To reach its goal, UCBC has defined four values: community life, service-oriented training, reflection and integration. The development of community life aims at creating opportunities for sharing experience and spiritual practices' through promoting a learning process that values principles such as mentoring and spiritual formation in all activities. Through service-oriented training UCBC longs 'to create an environment and to develop a Christ-like servant character in men and women who will become agents of transformation'. Through reflection UCBC wants 'to allow and promote dialogue and interactive learning in groups, so as to conciliate knowledge and practice and to formulate solutions that are relevant to the context of DRC'. Finally, through integration UCBC wants 'to develop a holistic ministry associating the mind, emotion and action in theology, politics and business for both individuals and communities'. UCBC’s motto is 'being transformed to transform' (CI-UCBC 2007).

UCBC's triadic training curriculum brings together academics, work and service. Academic training develops students’ academic inquiry skills and critical thinking. The training through work builds work ethic in students and it helps them to identify with the community in all sorts of work (manual, intellectual ...). Students have two hours of work per week for a certain compensation in tuition all along their training period at UCBC. Types of services offered in work program include 'on campus' services where students are organized in crews to care for their campus and 'community services'. The later consists in rendering service to the local community through any special activity (cleaning gutters, the market, public places, planting trees, flowers at round-about, etc.). Community services particularly involve all students, teaching and non-teaching staff and have had significant impacts on the population and students from other universities. The last component of the triadic curriculum is service- 
learning. Service-learning projects are curriculum based and they move students from classroom to the field in the community for shared benefit between students and the community. The community is taught and served and students maximize retention.

Finally, the integrated learning curriculum of UCBC includes macro and micro processes designed to develop learners into socially responsible citizens. These processes include institutional structures, values and ethos, academic and para-academic activities and assets, spiritual and cultural activities, infrastructural and social settings. The educational process at UCBC thus takes into consideration all formal and non-formal components of the learning curriculum. Within the formal component, where naturally in an academic subject curriculum, the teacher and the institution tend to be in the center of the learning activity, learners are placed at the center of the learning process. Within the non-formal component, the learner and the context are fully at the center of the educational process (Jusu 2015, 19).

\section{RESEARCH DESIGN, METHODS AND PROCEDURES}

To determine the nature of curriculum and the type of transformation that UCBC alumni experienced following their training in integrated learning, a qualitative approach with phenomenology as method was adopted. The design in this research purposed to obtain evidence to respond to the research questions and to discover and understand the experiences, perspectives, and thoughts of participants as McMillan and Schumacher $(1996,31)$ and Harwell (2011, 148) suggest for any qualitative study. The major questions that this article addresses are the following:

- What are the components of an integrated learning curriculum at a Christian University? What is integrated?

- How does an integrated learning curriculum impact learners to become transformation agents in their communities?

Generally, a phenomenological study provides the understanding of phenomena in their singular state (Van Manen 2014, 29). As such, this study throws light on the understanding of integrated learning for transformation and social responsibility as experienced by UCBC alumni.

From a total population of 93, twelve alumni were purposefully selected to participate in the study. Selection of participants was done to represent variation across four of the five faculties organized at UCBC - Theology, Economics, Communication and Applied Sciences. 
Three criteria were defined to select participants: (1) having studied for four years at UCBC, (2) having completed studies either in the academic year 2010-2011 or in the academic year 2011-2012, (3) be working in any institution at the time of study.

A letter seeking permission to do the study was sent to the management of UCBC. With the approval of the management, access to the list of students of all years was obtained. Three participants were selected in each of the UCBC four faculties. Four alumnae (females) also met the selection criteria (two in the Faculty of Communication, one in the Faculty of Economics and one in the Faculty of Applied Sciences). No alumnae in Theology Faculty met the selection criteria. After selection, participants were given informed consent letters which assured them free participation, anonymity and the right to withdraw from the study at any point.

Data was collected through one on one interviews scheduled at the place and time of convenience of participants. Interviews went on for an average of thirty to forty-five minutes and consisted of open-ended questions with occasional promptings in order to allow participants to recollect their experiences on the questions being asked and in so doing expand their ideas by way of their responses. Interviews were recorded, and the data collected was filed on a computer for verbatim transcription. And where necessary, transcripts were translated into English prior to analysis.

(1) The analysis of the twelve verbatim transcripts included six tasks that Creswell (2013) and Van Manen (2014) had declared were necessary in conducting a phenomenological analysis:

(2) Transcripts needed to be read several times in order to get an overall idea and feeling with regard to what was being said by participants in the interviews.

(3) Significant phrases and/or sentences that directly related to the experiences of the participants in interviews needed to be identifiedand, these significant phrases and/or sentences needed to be classified as relevant data while irrelevant data was to be discarded.

(4) Relevant data, according to Cresswell (2013) needed to be captured in in 'significant statements' or what van Manen (2014) refers to as 'meaning units'

(5) "Significant statements" or meaning units" should then be clustered into themes that are common in the recorded transcripts of all participants.

(6) A thick description of participants' experiences should then be made and this description should provide an understanding of the phenomenon under scrutiny and, an explanation of why participants experienced what they did, as revealed in their responses in the interviews

(7) Finally, a composite description should then be drawn up which represents an essential description of the phenomenon being investigated in each of the themes that emerged from the analysis of the collected data. 


\section{RESEARCH FINDINGS}

The analysis of the 12 verbatim transcripts resulted into two major themes, each with its clusters of formulated meanings. First of all, integrated learning for transformation is fruit of a multiple component and multiple dimension curriculum. The interconnectedness between the different components of the curriculum contributes to impact learners to act as change agents in their respective communities. Actually, learners are at the center of the social practices which serve as mold for transformation. The second emerging theme concerned how students are impacted to act as transformed citizens. The transformation that they experienced was defined as a chainlike process nourished by many concurring factors. Transformation takes learners from old assumptions to new assumptions as they are immersed in learning and social practices. Figure 1 presents the interconnectedness between components in the UCBC integrated learning curriculum model working towards transformation.

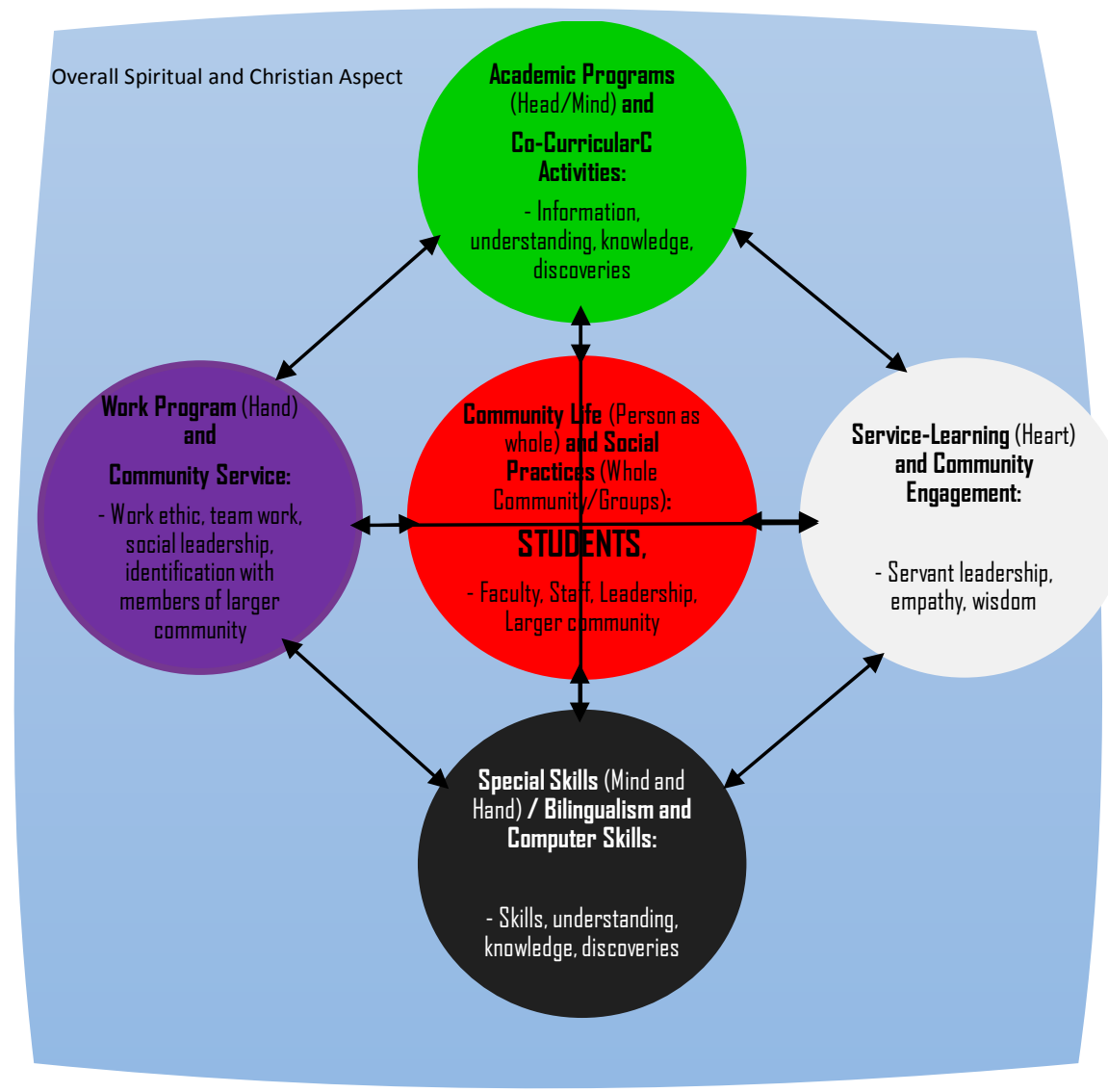

Figure 1: A representation of the interconnection between components in an Integrated Learning model for transformation

\section{Curriculum with multiple components and dimensions}

The integrated learning curriculum that induces transformation in learners comprises five interconnected components and four dimensions intertwined within these components. At the center of the curriculum is community life and social practices that evolve around learners. All 
other components of the learning community support learning through role modeling, preaching, mentoring, coaching, knowledge discovery, etc. to trigger change in learners and prepare them for the role they are to play in everyday life.

Participants experienced community life that they all described as family-like environment characterized by easy access to one another at all time without distinction of social rank, status, position, age, gender or race. Such interaction opened all members of the community up to the possibility of sharing burdens and problems through always having a person on whom to lean. A participant recognized that that doesn't happen in other institutions where the academic divide is strong and, it becomes difficult for people to disclose to one another at deeper levels. But at UCBC, a safe environment was developed which largely contributed to rich exchanges and interactions which induced transformation and healing (Sammut 2014).

Other components of the curriculum include specific skills training, academics, work programs and service learning. In this instance, specific skills trainings and the academic program component are integrated. To equip students academically, UCBC offers degree trainings in Theology, Economics, Communication, Applied Sciences and Law. This training is supplemented by specific skills training in English and computer skills in order to prepare students to cope with the linguistic and technological challenges they will confront in the modern and global world. According to Arnove (2007), breaking the linguistic and technological barriers in education helps to form citizens who are capable of bridging the dialectic of the global and the local in a world where the viability of the nation-state is challenged particularly on the African continent.

Participants experienced the academic training as a step towards understanding, knowledge acquisition and empowerment of learners to act wisely and apply accumulated knowledge to collective benefit. Academic training was described as particularly focusing on fostering motivation for achievement through emphasizing the context and background of the country, an approach that Alexandrov and Ramirez Velarde (2013) recognize as a motivator for learners. At UCBC a mandatory course called DRC Realities is designed for all freshmen. This course overviews the challenges of the country from various perspectives and it defines the role and responsibility that each citizen has to contribute to the betterment of life condition in community. Most participants experienced DRC Realities as a starter for transformation. One of them commented:

Just in the beginning we began the transformation ... the Congolese/DRC Realities [course]. It gave us a view ... it helped us to understand the situation that we are living in Congo. 
Other components: work program and service-learning contributed to develop engagement in learners with themselves and with the community. Work program was owned as community service and it developed work ethic, leadership skills, team work skills in learners and it also built in them a sense of accountability, responsibility and ownership for the care of their campus and the wider community. The latter, service-learning, took students from classroom to community to do meaningful services; it maximized retention, induced civic-mindedness and a spirit of servant leadership. A participant felt that they were not 'just there as researchers' but they regarded themselves as 'solution bringers to the community'. Describing one of the landmarks in transformation a participant said: '[service-learning] took away that inferiority, or superiority complex towards my wife or anybody. I really like to serve people in the community ... when I realize I served someone, I really sleep at peace.'

Four dimensions were identified along and intertwined with the five components discussed afore: the spiritual, the social, the moral and ethical, and the academic dimension. Integrated learning was primarily experienced as education similar to education offered by other universities but with emphasis on biblical/spiritual aspects. In fact, learners commented that at UCBC they were 'also trained spiritually ...' and felt they had 'to behave, to walk the talk ... a Christian character'.

Most participants perceived the spiritual side of education as targeting to encourage students build a relationship with God, the one Holmes (1987) says is source of all truth. The relationship with God is developed through the acknowledgement of the Lordship of Jesus Christ as Redeemer and the one who reconciles everything with God (Bower 2009). As a result of experiencing the spiritual dimension of training, three things occurred: some students demonstrated spiritual growth characterized by dependence on God, surrendering all gifts to God for service; the development of servanthood displayed through (service, humility, compassion, joy, integrity, honesty, etc.). Activities that contributed to spiritual growth consisted in social activities as well as bible related activities such as chapel sessions, reflection days, Bible studies, prayer sessions, retreats, choir activities, mentoring activities in social settings like houses, classrooms, student organizations, etc. All these activities brought about the growth of interactions and the building of relationships with one another without discrimination of staff, teachers and students. Chickering and Reisser (1993) recognize the importance of structural arrangements of an institution as a contributor to people affecting people. Balanced and healthy social interactions also have the capacity to ignite inner healing which places a person in position to genuinely give back to the community as an expression of gratitude. 
The moral and ethical dimension of the learning is carried out through the development of work ethic and values. The contributor to such development is the prevailing Christian worldview in the educational process of which role models are faculty and staff members and the settings are chapel sessions, Bible related course sessions, specialized general education course sessions, such as Civic Education and DRC Realities. Besides and together with these, academic subjects taught in different courses also contributed to empower as spontaneously expressed by most participants through the expressions: 'I can ...', 'I am able to ...', 'I am confident'.

\section{Integrated learning and transformation}

Integrated learning transforms students through equipping them to critically assess their previous and existing frame of reference and to develop new frames of reference that will help them to act as agents of transformation in their communities. Participants described transformation in similar terms to Mezirow's idea of transformation (1997) i.e. transformation is a process which changes your life and encourages a person to discover a new and more elaborated reality. A change process involves the building of knowledge, the acquisition of new knowledge and the implementation of solutions that are acquired through applying new knowledge to situations in one's own life or the community.

However, learners' personal motivation and desire to seek transformation was also emphasized. Participants recognized four points as preparation for transformation to be successful. First, the learner needs to know what he/she wants to study and why; this entails matching personal gifts with passion. Secondly, the learner needs to have a right motivation for studies, his/her choice needs to be autonomous and not a result of influence by external factors. Thirdly, he/she needs to define a vision and set a high goal consisting in the willingness to give back to the community. Lastly, the learner needs to make an effort to develop the capacity to solve problems.

Scholars such as (Pagels 1979; Mezirow 1997; McCahill 2006; Hart 2009; Butcher, Egan and Howard 2009; Freire 2010; Ntamushobora 2012) have written on transformative learning. They agree with the departure point of change i.e to understand the existing challenges and to gain consciousness in a reflective action. This is a key step for learners to move towards new assumptions and transformation. At the UCBC learners experienced integrated learning as an empowerment to provide them with a context to revisit their own assumptions, beliefs, context and broader environment and to develop new assumptions or simply elaborate on the old ones. New assumptions drove learners to act through service-learning and community service as they 
strive to reach their new defined goals (personal layer) or the community goals (social layer). The value structures and assumptions of learners on a personal level were challenged and redefined which contributed to character development. At social layer, assumptions on socioethical value structures of the community and of the nation were challenged both in learners and people they encountered. The described result was change triggered in community members to act justly. In other words, learners experienced an impact of transformation that Ntamushobora (2012) has also examined in his doctoral dissertation which consists in unveiling the learner's awareness concerning his/her personal, historical, cultural, social, relational and even spiritual context with the commitment to act and live a life guided by new and better assumptions for him/her and the community.

However, contrarily to Ntamushobora's study which substantiates transformation among Christian students in some university of Kenya, an Anglo-Saxon education context, this article establishes that integrated learning that is transformational triggers the same in a Frenchspeaking country educational context. In the DRC, a former Belgian colony, education has remained theory and memorization oriented and critical thinking is less emphasized. The experience of UCBC brings a contribution that can be of value to many other institutions in the Anglo-Saxon as well as French speaking countries in sub-Saharan Africa.

\section{CONCLUSION}

The purpose of this article was to describe educational curriculum that impact learners' personal lives to make them servant leaders with social responsibility. The transformation experience was examined through a qualitative interview inquiry involving lived experiences of twelve alumni from the UCBC in the DRC.

Findings have established two basic facts in relation to the query posed in the introduction of this article. First, the integrated learning curriculum that triggers transformation was described as having multiple components and dimensions. Learners are equipped with academic skills and special skills through course subjects and training in bilingualism and technology handling. The curriculum also prepares learners to be servant leaders through work program and service-learning. Lastly, through the community life, the curriculum nurtures free interaction, mentoring and coaching which impact inner lives. All these components are undertaken within the Christian worldview frame.

Secondly, transformation is experienced as a chain like process in which learners grew in consciousness of their responsibility to give back to the community in a selfless way. Once commissioned in community for work, learners could display different character and they 
became role models to those around them. These findings have substantiated that integrated learning does not only change learners' lives, but it also induces change in the community through learners acting as learning-teachers.

Like all qualitative studies, results of this research are not generalizable. However, the essence of the phenomenon was used to inspire implications for the implementation of integrated learning curriculum in South Africa context. Results of this study can also be extended to other educational contexts on the African continent and in the world on the ground of adaptability.

\section{NOTE}

1. Forget about the former things; do not dwell on the past. See, I am doing a new thing! Now it springs up; do you not perceive it? I am making a way in the desert and streams in the wasteland. (Holy Bible, Isaiah 43:18-19).

\section{REFERENCES}

Alexandrov, N. S. and R. V. Ramirez-Velarde. 2013. The integrated learning process, metacognition, and collaborative learning. In Technological advances in interactive collaborative learning, ed. N. S. Alexandrov, Ramirez-Velarde and V. Alexandrov. Boca Raton: CRC Press.

Arnove, R. F. 2007. Introduction: Reforming comparative education: The dialectic of the global and the local. In Comparative education: The dialectic of the global and the local, ed. R. F. Arnove and C. F. Torres. Lanham/Boulder: New York/Toronto/Plymouth. UK: Rowman \& Littlefield Publishers.

Bower, L. 2009. Faith-learning interaction in graphic design courses in Protestant Evangelical Colleges and universities. Christian Higher Education 9(1): 5-27.

Briscoe, S. 1987. The communicator's commentary: Genesis, General ed. L. J. Ogilvie. Waco, Texas: Word Books, Publisher.

Butcher, J., L. A. Egan and P. Howard. 2009. Community and transformational education. Paper presented at the AARE Annual Conference. Canberra.

CI-UCBC. 2007. Strategic plan. Beni, DRC: Unpublished.

Chickering, A. W. and L. Reisser. 1993. Education and identity. $2^{\text {nd }}$ Edition. San Francisco/USA: Jossey-Bass Publisher.

Cranton, P. and E. W. Taylor. 2012. Transformative learning theory: Seeking a more unified theory. In The handbook of transformative learning: Theory, research and practice, ed. E. W. Taylor and P. Cranton. San Francisco: Jossey-Bass.

Creswell, J. W. 2013. Qualitative inquiry and research design: Choosing among five approaches. Los Angeles, London, New Delhi, Singapore, Washington DC: SAGE.

Freire, P. 2010. Pedagogy of the oppressed. New York: Continuum.

Glanzer, P. L. 2008. Why we should discard 'the integration of faith and learning': Rearticulating the mission of the Christian scholar. Journal of Education and Christian Belief 12(1): 41-51.

Gunnlaugson, O. 2008. Metatheoretical prospects for the field of transformative learning. Journal of Transformative Education 6(2): 124-135.

Hart, T. 2009. From information to transformation. Education for the evolution of consciousness. New York: Peter Lang. 
Harwell, R. H. 2011. Research design in qualitative/quantitative/mixed methods. In The SAGE handbook for research in education, ed. C. F. Conrad and R. C. Serlin. $2^{\text {nd }}$ Edition. Los Angeles/London/New Delhi/Singapore/Washington DC: SAGE.

Henning, E., W. van Rensburg and B. Smit. 2004. Finding your way in qualitative research. Pretoria: Van Schaik Publishers.

Holmes, A. F. 1987. The idea of a Christian college. Grand Rapids, Michigan, the United States of America: Wm. B. Eerdmans Publishing Co.

Holy Bible. 1984. Kenya: International Bible Society - Africa.

Jusu, J. 2015. Research-based curriculum review: Learning from the Africa leadership study. InSights Journal for Global Theological Education 1(1): 17-29.

Luke, A., A. Woods and K. Weir. 2013. Curriculum design, equity and the technical form of the curriculum. In Curriculum, syllabus design and equity: A primer and model, ed. Allan Luke, Annette Woods and Katie Weir. New York and London: Routledge.

McCahill, C. 2006. Transformative learning and teaching: The Fourth Gospel and the Christian religious educator. Religion Journal of Australia 22(2): 20-25.

McMillan, J. H. and S. Schumacher. 1996. Research in education: Evidence-based inquiry. Boston: Pearson.

McNeil, J. D. 1985. Curriculum: A comprehensive introduction. Boston, Toronto: Little, Brown and Company.

Mezirow, J. and Associates (Eds.). 1990. Fostering critical reflection in adulthood. A guide to transformative and emancipatory learning. San Francisco: Jossey-Bass Publishers.

Mezirow, J. 1997. Transformative learning: Theory to practice. In Transformative learning in action, Vol. 74: New directions for adult and continuing education, ed. P. Cranton, 5-12. San Francisco: Jossey-Bass.

Mezirow, J. 2012. Learning to think like an adult: Core concepts of transformation theory. In The handbook of transformative learning: Theory, research and practice, ed. E. W. Taylor and P. Cranton. San Francisco: Jossey-Bass, a Wiley Imprint.

Nemerowicz, G. and E. Rosi. 1997. Education for leadership and social responsibility. London/Washington D.C.: The Falmer Press.

N'Sial, S. C. 2007. Former pour Transformer [To train in order to transform]. Kinshasa: Edition de la C.P.E.

Ntamushobora, F. 2012. From transmission to transformation: An exploration of education for holistic transformation in selected Christian and public universities in Kenya. Doctoral Thesis. Biola University: USA.

Pagels, E. 1979. The Gnostic Gospels. New York: Random House.

Poland, B. D. 2002. Transcription quality. In Handbook of interview research: Context and method, ed. J. F. Gubrium and J. A. Holstein, 33-54. London: Sage.

Sammut, K. 2014. Transformative learning theory and coaching: Application in practice. International Journal of Evidence Based Coaching and Mentoring Special Issue, June (8): 39-53.

UCBC. 2009. LMD (Licence-Maîtrise-Doctorat) Project. Beni, DRC: Unpublished.

Van Manen, M. 2014. Phenomenology of practice. Meaning-giving methods in phenomenological research and writing. Walnut Creek, California: Left Coast Press.

VanZanten, S. 2011. Joining the mission. A guide for (mainly) new college faculty. Grand Rapids, Michigan, the United States of America: Wm. B. Eerdmans Publishing Co. 